\title{
World Englishes, Critical and Feminist Pedagogies Coalition in Pre-service Teacher Training
}

\author{
María A. Barros-del Río ${ }^{1}$ \\ ${ }^{1}$ Faculty of Humanities and Communication, University of Burgos, Spain \\ Correspondence: María Amor Barros del Río, Faculty of Humanities and Communication, University of Burgos, \\ Spain, SP., 09001, Calle Villadiego s/n. Tel: 34-947258788. E-mail: abarros@ubu.es
}

Received: December 6, 2015 Accepted: January 18, 2016 Online Published: January 19, 2016

doi:10.5539/elt.v9n2p192

URL: http://dx.doi.org/10.5539/elt.v9n2p192

\begin{abstract}
In an attempt to overcome the fragmentation of theoretical and practical post-structuralist strands applied to the teaching of EFL, this article explores how critical and feminist perspectives can inform the TESOL practice through the inclusion of the voices and experiences of those who have been excluded from dominant discourses according to the World Englishes classification. After exposure to basic readings on feminist and critical pedagogies, a group of pre-service teachers enrolled in the Master's degree in teaching at the University of Burgos in Spain, were asked to design teaching activities for the selected authentic materials. Malala Yousafzai's speech to the UN in 2013 was selected so that the pre-service teachers would face nonnative texts. Through the didactic exploitation of her discourse, gender, power, identity and violence issues were addressed. Results indicate that coalition of World Englishes, feminist, and critical pedagogies enhance resistance to dominant discourses, foster awareness in teaching practices and contribute to social transformation. Further scholarly reflection and classroom practices are suggested on the relationship between the use of English as a globalized language for training purposes and its relationship with the particular struggles of the oppressed.
\end{abstract}

Keywords: teacher training, EFL, critical pedagogy, feminist pedagogy, World Englishes, TESOL

\section{Introduction}

\subsection{Fragmentation of Post-Structuralist Strands}

In the last decades, much academic literature has shown interest in the use of English language as a means for international communication. For some, this phenomenon is the result of imperialistic interests, an imposition that needs to be resisted (Canagarajah, 1999; Phillipson, 1992; Park \& Wee, 2009). For others, English has been sought out by people due to its usefulness in a globalised world (Brutt-Griffler, 2002; Davies, 1996). Although this debate is still open, there are noticeable cultural, linguistic, ideological and other differences among speakers of English worldwide that affect the uses of the English language globally, giving birth to many varieties. In an attempt to conceptualize this phenomenon, Kachru (1985) proposed the "Three Circles of English", a classification to explain the spread of English and its varieties. In his World Englishes (WE) model he distinguished an inner circle that would comprise the countries where English stands as a native language, an outer circle that would include the countries affected by British colonization, and an expanding circle that would contain those countries where English is widely used. Under this lens, the teaching of English as a widely used language necessarily affects the way we teach it.

Many works have challenged the alleged neutrality of languages from critical and feminist perspectives (Agray Vargas, 2007; Appleby, 2009; Barnawi, 2010) converging on the existence of a cultural hegemony where underlying power relations validate certain teaching praxis, legitimize some human experiences as universal and define what interpretations are appropriate in each situation. Freire's (1970) contributions to critical pedagogy (CP) denounced social inequalities and heightened the role of education as a key tool to empower the oppressed and help them regain their dignity. Consequently, education becomes a political act that shatters a hidden power balance to put the oppressed in the centre. But the distinction between the oppressors and the oppressed in Freire's first works did not clearly acknowledge the diversity of contexts and experiences within these two opposing groups, a matter that was partially incorporated in his later works. Although TESOL has probably been "one of the last academic disciplines in the field of humanities and social sciences to go critical" (Kumaravadivelu, 2006, p. 70), insightful works have been devoted to enlarging these two fields (Bruthiaux, 
2010; Flores, 2013; Kumaravadivelu, 2014; Mahmoodarabi \& Khodabakhsh, 2015; Matsuda, 2003).

On it side, feminist pedagogy has added some valuable insights to CP following the "difference" track in the TESOL field and considering EFL and ESL classrooms as "unique spaces where different linguistic and cultural worlds come into contact" (Norton \& Pavlenko, 2004, p. 509). Coalition between CP's scope and feminist perspectives for TESOL purposes would seem a natural partnership as emphasis is placed on the concrete and particular rather than on the global, and the understanding of agency and emancipation as personal and individual experiences become shared features. Also, since the publication of Feminisms and Critical Pedagogy (Luke \& Gore, 1992), other works have addressed this combination that surely shares an ethical stance. For instance, a special issue of TESOL Quarterly (Davis \& Skilton-Sylvester, 2004) addressed the relationship between gender and English Language Teaching (ELT) from many perspectives.

But despite these attempts at addressing TESOL from a more comprehensive and inclusive perspective, World Englishes, critical pedagogy and gender pedagogy seem to have walked three separated paths that have rarely met. Hence, the purpose of this study is to offer a plausible coalition of these different fields in the form of innovative formulae that incorporate "action-oriented counter-hegemonic strategies" (Kumaravadivelu, 2014, p.14 ) in the TESOL practice. For this, it is necessary to deviate attention from hegemonic topics so that the increasingly larger marginal voices are privileged and, at the same time, to resist centre-based methods in order to foster active and critical prospective ESL/EFL teachers. Previous attempts in pre-service treacher training had combined the critical pedagoy principles and Kachru's "Three circles of English" model with unsatisfactory results (Barros del Río, 2015). Now, this article offers innovative instructional strategies that combine critical and feminist perspectives to better inform the TESOL practice through the inclusion of the voices and experiences of those who have been excluded from dominant discourses according to the World Englishes classification.

\subsection{The Need of a Coalition}

In the belief that $\mathrm{CP}$ and feminist pedagogy enhance reflection and reaction to asymmetrical power relations in TESOL practices, a specific instructional strategy was designed for a group of pre-service teachers. In particular, this study began exposing them to basic materials on WE, feminist and critical pedagogies to foster their acquaintance with these strands. Once they were familiar with them, an authentic outer-circle text sample was chosen and the pre-service teachers were encouraged to develop corresponding teaching strategies following the previously seen criteria. Finally, assessment of critical and gender awareness would inform the validity of the selected approaches to enlighten further research and experiment. This article documents the process they underwent, the issues they debated, the controversies they met and the solutions they found to project the internationality of English from a critical and feminist stance, as prospective teachers of English.

\section{Method}

Training pre-service teachers offers a unique context to promote equitable and democratic approaches in the teaching practice. That is why this teaching project was conducted within the framework of an EFL Master's degree in education at the University of Burgos, Spain, a one year full-time professional training course for graduates who wish to work in the teaching field. It was developed by a group of eight Spanish pre-service students enrolled in the course "Foreign Language: English, Contexts and Situations". Inspired by CP and gender approaches and framed within the World Englishes classification, the goal of this project was threefold. Firstly, it aimed at denouncing injustice and women's exclusion from hegemonic discourses in the teaching of English. Secondly, it sought to foster among the pre-service teachers awareness and active involvement in critical and feminist TESOL practices. Thirdly, it pursued to develop a consciousness on the diversity of Englishes existing in a globalized world and its implications for pre-service teachers in TESOL.

At the beginning of the course, selected readings were handed out (Crystal, 2012; Giroux, 1985; Norton \& Pavlenko, 2004) and some sessions were devoted to discussion. The novelty of these approaches not only demanded much talking and reconsideration of concepts previously learnt but also the willing acceptance of a new lens. Once they were familiar with it all, some real materials could be presented so that they could debate and design corresponding teaching practices. To transform the course into a liberating practice, three progressive steps were taken. Firstly, it was necessary to read and listen to the voices of the marginalized so that they were heard and recognized as existent. Positioning the little and the poor at the centre makes their linguistic productions valuable. Secondly, deconstruction of dominant values to challenge hegemonic ideologies had to take place. If dominant values do not promote equity, they must be denounced and subverted. Thirdly, engagement and action were needed to accommodate new perspectives and practices that promote dignity and worthiness for all. To achieve those three goals, specific strategies need to be implemented. In particular, the 
pre-service teacher training course paid special attention to curricular innovation and topic management as key aspects to test feminist and critical approaches in the frame of outer-circle Englishes (Norton \& Pavlenko, 2004).

As the use of authentict materials was mandatory, Malala Yousafzai, the 2014 Nobel Peace Prize, was chosen for her commendable struggles in favour of all children's right to education. Undoubtedly, the issue met many of our requirements as the protagonist was a real person born in an impoverished country, Pakistan, with a history of British colonisation. More importantly, her work dealt with problematic situations and it concerned "real-world issues meaningful to the students" (Crookes \& Lehner, 1998, p. 320), a fact that could foster deeper engagement and personal development among the pre-service teachers. In particular, Malala Yousafzai's speech to the UN (2013) was selected again as the starting point of the teaching projects that the pre-service teachers had to design (Barros del Río, 2015). Her words voiced the experience of millions of people around the world who have inherited English as an official language in their territories, as is the case in Pakistan. Also, her demands for the right to education were a suitable issue to deal with from $\mathrm{CP}$ and gender perspectives. Besides, it was found suitable for curricular innovation purposes, as it elevated a female teenager's discourse to the rank of a text of study. As a result, the pre-service teachers were exposed to a challenging topic that comprised an array of perspectives: World Englishes, gender, education, violence and postcolonialism.

After contextualizing and visualizing Malala Yousafzai's speech, only a part of her discourse was selected as reading material (from min. 10'30" to min. 15'43"). Sufficient time was devoted to its reading and understanding. Collectively, it was agreed that the text explored three main ideas, i.e., correlation between peace/violence and education; a series of demands to rulers and communities; and self-empowerment to achieve change. Then the pre-service teachers were asked to work in groups to discuss and agree on the orientation of their teaching proposals using critical and feminist approaches. In practice, each group worked independently but all productions were shared and commented. As a result, most of the designed activities focused on Malala's suffering but also on her vindications and dreams. Some of them paid more attention to the topics, others focused on grammar and lexis but all approaches were directed towards reflecting from critical and gender perspectives what confirmed the relevance of pre-readings for analysis orientation.

\section{Results and Evaluation}

Among all the activities the groups produced, some have been selected to illustrate the processes undergone by the pre-service teachers. In the first instance, attention was devoted to facilitate comprehension and familiarity with the text. One group paid special attention to Malala's expression "we call upon", asking to underline it in the text to acknowledge its frequency. The degree of assertiveness extracted from the text was noticed and as one of the groups suggested, something similar could also be found in other historical texts. The pre-service teachers agreed that intertextuality was a fertile ground for teaching purposes in the context of World Englishes and names such as Wangari Maathai, Mahatma Gandhi and Nelson Mandela, among others, were written down. Enthusiasm was then a common feeling in the classroom as the pre-service students detected the many possibilities for a critical teaching that were awaiting them.

Also identity and agency were issues that attracted much attention among the pre-service teachers. A much peer-commented activity aimed at matching Malala's requests and rights with their corresponding subjects. In her urgent request for global change, Malala had involved herself when addressing her audience as "brothers and sisters", something that had already been detected in classroom dialogues. So, the pre-service teachers focused their attention on the World Englishes' variations in the text, some of which might be attributed to language transfer from Malala's mother tongue. Ignorance on this linguistic phenomenon led to discussions about the presence of expressions not commonly used in inner-circle Englishes and extra readings on the matter were suggested (Koda \& Reddy, 2008). Already at this early stage, the text comprehension activities designed by the pre-service students tackled multiculturalism and plurality in the English language and strengthened identification between the readers and the speaker.

Linguistically, all groups focused on lexical patterns in the text, and more specifically on word formation through prefixes. Besides repetition for rhetorical effect, Malala's discourse was characterized by its semantic content. Thus, a range of activities focused on synonyms and antonyms formation such as fair/unfair; violent/non-violent; educated/uneducated; dependent/independent. The selected vocabulary blatantly invoked the structural violence children, especially girls, face around the world. When asked why they had focused on antonyms, all groups referred to the striking strength of Malala's words in terms of oppression and violence. Also from a gender perspective, they argued that Malala's discourse spoke of identities in conflict, as millions of girls suffer from deprivation of the right to education, a form of structural violence.

Finally, a third and last phase focused on independent production. As CP insists on the importance of autonomy 
and performativity, group reflection was turned towards engagement. All groups designed several activities encouraging the expression of ideas and the use of the previously seen vocabulary. In general, English was conceived as a tool for communicating new insights and critical reflections enlightened by the text and the previous activities. For example, one activity focused on essay writing after visiting the ad campaign from the electronic UN Women section denouncing gender-biased discourses. Another activity consisted of selecting a piece of news or an ad and debating the chosen item from a gender perspective; later, it would have to be presented and analysed from a critical perspective front of the class. All these activities aimed at provoking critical reflection on students as users of media and recipients of their cultural constructions in terms of gender inequalities and violence.

Despite it all, none of the activities designed by the pre-service teachers was orientated towards a move into transforming praxis. Whereas awareness and critical standpoints were at the core of every activity, actual transformation of facts was missing. That inability may have been the result of the geographical and cultural distance between Malala's outer-circle struggle and the pre-service teachers' expanding-circle experiences even though the authenticity and the power of the materials used were unquestionable. Correspondingly, the inclusion of outer-circle Englishes and the oppressed in the EFL classroom remains a challenging concern.

To assess the whole experience, an evaluation sheet was passed around. One of the questions was "Do you think your prospective students would engage with the topic?". The collected answers indicated a divergence of opinions within the group. One student answered: "I think they would like this subject because Malala is their age and they may identify with her. Besides, it can make them think of ways to change things even in Spain, where obviously we live in better conditions". Another answer was: "I hope this topic would at least make them think about their education and life and compare themselves with this girl". According to these answers, both students showed critical stances towards inequity. Working with Malala's speech also provided them with an authentic example of a subaltern's use of the English language. On the contrary, another student wrote: "I do not think they would engage completely because I do not think they have enough knowledge (and therefore interest) of human rights". And another answer was: "It depends, maybe some special group would, but generally not". The wide range of opinions within the group of pre-service teachers shows fragmentation of perspectives and attitudes towards action.

To the question "Have the topic and sub-topics been interesting/useful to you?", they all answered positively. They all referred to Malala's claim for action against violence and illiteracy as a turning point in their attitude towards the teaching practice. Particularly, one student wrote: "We have shared very good ideas of teaching and I also think that our personalities are seen in them". These remarks indicate a certain degree of personal engagement in the creation of new activities and teaching projects.

In sum, the pre-service teachers underwent a process of consciousness in their own teaching projects. They got involved and they designed pedagogical strategies to involve others too

\section{Discussion}

In the first place, the classroom practices previously detailed show that a careful selection of reading materials in the EFL classroom is an essential phase that may contribute to subsequent transformative language teaching practices. As suggested by several scholars (Kumaravadivelu, 2014; Sung, 2014), doing proactive research and acquiring some degree of familiarity with the selected post-structuralist strands and WE is a crucial phase to give room to the classroom's perspectives development.

Secondly, according to CP principles, exposition to problematic texts proved mandatory in order to foster critical awareness. Reception of Malala's speech was positive and her message was suitable to complicate the western hegemony in ELT and to combat the denial of agency of the poor, especially women. The broad array of topics tackled by the selected discourse made the pre-service teachers acknowledge the enormous potential of applying feminist and critical approaches to authentic materials for classroom exploitation. That suggests that a suitable pre-reading selection exerts a powerful influence in the subsequent orientation of debates and teaching practices.

Malala's discourse caused not only emotional attachment but also critical analysis and response to the problematic issues it posed. The activities designed by the pre-service teachers showed an interest in underlying cause-effect relations of inequalities, so that students could delve into the problematic topics the discourse denounced. Emphasis was also made on word formation to underline issues of violence, power and oppression. In particular, Malala's discourse epitomized an act of resistance.

Both $\mathrm{CP}$ and feminist pedagogies promote autonomy in learning, thus autonomous group working contributed to enriching but also distracting debates. Especially at the beginning of the production phase, the pre-service 
teachers showed a tendency to topic dispersion what required occasional redirection from the trainer who acted as a facilitator or an accompanying figure.

Thirdly, shortcomings in actual engagement for social transformation beyond the classroom walls suggest that the inclusion of problematic issues in curricular content and topic management is not enough for pre-service teachers to take action. In the case of Spanish pre-service teachers, outer-circle materials, as well as expanding-circle and inner-circle productions, might be too distant from their actual experiences. This would call into question the use of Kachru's classification together with CP and feminist approaches for Spanish pre-service teacher training. At the same time, this conclusion opens new and very interesting questions. Had the pre-service teachers come from an outer-circle country, would their responses have been different? What kind of discourses can identify non-native pre-service teachers from expanding-circle countries with?

Many more experiences worldwide are needed to explore the relationship between exposure to problematic materials and engagement in the classroom. Also, more comprehensive combinations of post-structuralist strands for transforming teaching practices are needed so that engagement and transformation are fostered through the teaching praxis. Regarding this case study, whether exposure to problematic issues and a critical response to injustice are enough for feminist and critical purposes remains an open question.

\section{Conclusions}

While the TESOL practice has been accused of aligning with imperialistic interests that marginalize the experiences and potentialities of the "subaltern" (Kumaravadivelu, 2014), the post-structuralist attempts at addressing alternative approaches have taken separated paths and, therefore, given partial responses to the contoversy of cultural hegemony that is hidden underneath. Critical and feminist pedagogies should be used as imperative strands to enhance reflection, participation and autonomy in pre-service teacher training, as well as World Englishes approaches should contribute to a more diverse and de-centered conception of the teaching practice. This article has presented an experimental study that combines those three perspectives in order to improve the quality of prospective ESL/EFL teachers' training and foster their engagement.

Results indicate that the existing gap due to the diverging paths that World Englishes, feminist, and critical pedagogies have followed for too long in the field of TESOL, can be filled. As demonstrated, the convergence and alliance of these post-structuralist strands enhance resistance to dominant discourses, foster awareness in teaching practices and contribute to social transformation in the form of comprehensive and inclusive teaching strategies.

This experimental study has demonstrated that the proposed coalition contributes to emancipatory processes in the form of liberating teaching practices. Added to this, contentious issues such as identity, globalization, postcolonialism and poverty are easily found when using the World Englishes classification for teacher training purposes. Exposure to non-inner-circle Englishes brings along social and cultural contexts too frequently unnoticed by teachers and students. Thus, legitimation of the unvoiced becomes a way to resist linguistic imperialism and the power forces that construct inequalities. This supports the selection of authentic and problematic materials as a key aspect that needs to be preserved. Accordingly, $\mathrm{CP}$ is revealed as a transforming and powerful tool that may change teachers' and students' perspectives and lead them to actual engagement for a better world. Likewise, the use of feminist pedagogies helps narrowing the focus of study and giving back their dignity to the most oppressed among the oppressed. Both approaches share essential foundations that complement each other, placing the focus of interest on the poorest among the poor: girls and women.

Finally, despite exposure to a problematic text from the outer circle and the use of critical and feminist pedagogies in the training process, action did not go beyond acknowledgment of gender-biased discourses and practices in the pre-service students' daily lives, nor actual mobilization against their own oppressive experiences did occur. That indicates that the inclusion of non-western discourses in the curriculum content may not be enough to move them to action. Added to this, a "transition period" may also be necessary to allow more time and practice (Rashidi \& Safari, 2011). More classroom practices and further scholarly reflection must be done on the relationship between the uses of English as a global language and the particular struggles of the oppressed who appropriate it as a means of expression. Finally, more innovative approaches to the teaching of World Englishes from critical and gender perspectives are needed, especially in contexts where English is studied as a second or foreign language.

\section{References}

Agray Vargas, N. (2007). Currículo emancipatorio y enseñanza de lenguas extranjeras. ¿Ficción o realidad?. Gist: Education and Learning Research Journal, 1, 115-124. 
Appleby, R. J. (2009). Do we make a difference? Gender and English language teaching in international development. In H. Chen, \& K. Cruickshank (Eds.), Making a Difference: Challenges in Applied Linguistics (pp. 83-96). Newcastle Upon Tyne: Cambridge Scholars Publishing.

Barnawi, O. Z. (2010). Pedagogical tasks for fostering critical transformative EFL teachers: pre-service EFL teacher-educators. The Journal of International Social Research, 3(4), 107-119.

Barros del Río, M. A. (2014). Promoting Critical Awareness in Spanish Pre-service ELT Training: A Chance to Change the World?. International Journal of English and Education, 4(3), 252-263.

Bruthiaux, P. (2010). World Englishes and the Classroom: An EFL Perspective. TESOL Quarterly, 44, 365-369. $\mathrm{http}: / / \mathrm{dx}$. doi.org/10.5054/tq.2010.222223

Brutt-Griffler, J. (2002). World English: A study of its development. London: Multilingual Matters.

Canagarajah, A. S. (1999). Resisting linguistic imperialism in English teaching. Oxford: Oxford University Press.

Crookes, G., \& Lehner, A. (1998). Aspects of Process in an ESL Critical Pedagogy Teacher Education Course. TESOL Quarterly, 32(2), 319-328. http://dx.doi.org/10.2307/3587586

Crystal, D. (2012). A global language. In P. Seargeant, \& J. Swann (Eds.), English in the world: history, diversity, change (pp. 152-157). Abingdon: Routledge. http://dx.doi.org/10.1017/CBO9781139196970

Davies, A. (1996). Ironising the myth of linguicism: Review article. Journal of Multilingual and Multicultural Development, 17/6, 485-596. http://dx.doi.org/10.1080/01434639608666297

Davis, K. A., \& Skilton-Sylvester, E. (2004). Looking Back, Taking Stock, Moving Forward: Investigating Gender in TESOL. TESOL Quarterly, 38, 381-404. http://dx.doi.org/10.2307/3588346

Flores, N. (2013). The Unexamined Relationship Between Neoliberalism and Plurilingualism: A Cautionary Tale. TESOL Quarterly, 47, 500-520. http://dx.doi.org/10.1002/tesq.114

Freire, P. (1970). Pedagogy of the oppressed. New York: Herder and Herder.

Giroux, H. A. (1985). Teachers as transformative intellectuals. Social Education, 49(5), 376-79.

Kachru, B. (1985). Standards, codification and sociolinguistic realm: the English language in the outer-circle. In R. Quik, \& H. Widdowson (Eds.), English in the World: Teaching and Learning the Language and Literature (pp. 11-30). Cambridge: CUP.

Koda, K., \& Reddy, P. (2008). Cross-linguistic transfer in second language reading. Language Teaching, 41, 497-508. http://dx.doi.org/10.1017/S0261444808005211

Kumaravadivelu, B. (2006). TESOL methods: Changing tracks, challenging trends. TESOL Quarterly, 40, 59-81. http://dx.doi.org/10.2307/40264511

Kumaravadivelu, B. (2014). The Decolonial Option in English Teaching: Can the Subaltern Act? TESOL Quarterly, 1-20. http://dx.doi.org/10.1002/tesq.202

Luke, C., \& Gore, J. (Eds.) (1992). Feminisms and critical pedagogy. New York: Routledge.

Mahmoodarabi, M., \& Khodabakhsh, M. R. (2015). Critical Pedagogy: EFL Teachers' Views, Experience and Academic Degrees. English Language Teaching, 8(6), 100-110. http://dx.doi.org/10.5539/elt.v8n6p100

Matsuda, A. (2003). Incorporating World Englishes in teaching English as an Interantional Language. TESOL Quartely, 37, 719-729. http://dx.doi.org/10.2307/3588220

Norton, B., \& Pavlenko, A. (2004). Addressing gender in the ESF/ESL classroom. TESOL Quarterly, 38(3), 504-514. http://dx.doi.org/10.2307/3588351

Park, J. S., \& Wee, L. (2009). The three circles redux: A market-theoretic perspective on world Englishes. Appplied Linguistics, 30(3), 389-406. http://dx.doi.org/10.1093/applin/amp008

Phillipson, R. (1992). Linguistic imperialism. Oxford: OUP.

Rashidi, N. \& Safari, F. (2011). A Model for EFL Materials Development within the Framework of Critical Pedagogy (CP). English Language Teaching, 4(2), 250-259. http://dx.doi.org/10.5539/elt.v4n2p250

Sung, C. C. M. (2014). Exposing learners to Global Englishes in ELT: some suggestions. ELT Journal, 69(2), 198-201. http://dx.doi.org/10.1093/elt/ccu064

Yousafzai, M. United Nations Youth Assembly discourse. (2014, November 13). Retrieved from 
https://www.youtube.com/watch?v=3rNhZu3ttIU

\section{Copyrights}

Copyright for this article is retained by the author(s), with first publication rights granted to the journal.

This is an open-access article distributed under the terms and conditions of the Creative Commons Attribution license (http://creativecommons.org/licenses/by/3.0/). 